\title{
Impact of Using the Differentiated Instruction (DI) Strategy on Student Achievement in an Intermediate Stage Science Course
}

\author{
https://doi.org/10.3991/ijet.v16i11.22303 \\ Najeh Rajeh Alsalhi ${ }^{(\varpi)}$ \\ Ajman University, Ajman, UAE \\ n.alsalhi@ajman.ac.ae \\ Rasha Abdelrahman \\ Ajman University, Ajman, UAE \\ National Center for Examination and Educational Evaluation, Egypt. \\ Atef F. I. Abdelkader \\ Ajman University, Ajman, UAE \\ Sharif S. Ahmad Al-Yatim, Mahmoud Habboush, Abdellateef Al Qawasmi \\ Ministry of Education-Jordan
}

\begin{abstract}
This study aimed to investigate the impact of using the differentiated instruction strategy on students achievement in an intermediate school course and their attitudes towards it. The study was conducted using a semi-experimental method. Participants were 483 students, split into two groups: empiric $(n=244)$ and control $(n=239)$. Achievement tests and questionnaires were used as tools for this study. Data analyzed through the SPSS program. The results indicated that there were statistically significant differences between the groups for the benefit of the empiric group that taught via DI. The results also revealed positive attitudes towards the strategy used. The study recommends that attention to applying the differentiated teaching strategy for teaching science curricula and other textbooks.
\end{abstract}

Keywords-Attitudes, Differentiated instruction strategy, Intermediate Stage, Science achievement.

\section{$1 \quad$ Introduction}

The educational system has continuously changed as a result of the rapid development of scientific knowledge and technology in today's 21 st century, which has led to modern methods of teaching being increasingly used and applied, especially in developing countries. In order to increase and improve the level of educational outcomes and to address the deficiencies and drawbacks of traditional teaching methods which restrict the thinking of both the teacher and the student[56]. Modern teaching methods cover 
all essential components of the educational system, including teacher, student, curriculum, and school[2, 39]. This will provide a high opportunity for both the teacher and the student to interact with each other, within the framework of scientific rules and foundations that ensure students' understanding of the highest level of knowledge and facts[33]. The theory of multiple intelligences considers one of the modern trends that addressed the individual differences between learners. This has contributed to a major shift in the study of individual differences between learners, that education experts in the education sector have been led to look for effective education strategies and approaches to address these differences between students[15, 44]. According to [32], strategy is described as a collection of methods, procedures, and structured techniques that are used to achieve what is needed objectives on time, taking into account the available financial and material resources and efforts. Differentiated instruction (DI) considered one of the most modern and advanced teaching strategies, which many countries have started using and applying to take into account the different needs, inclinations, and interests of students, and the differences between their levels in understanding.

\section{Theoretical Background}

\subsection{Education in the Jordan}

Education in Jordan is one of the best education systems in the countries of the world. Education plays a pivotal and vital role in the life and culture of Jordanian society. The effective education system has made a significant contribution to making Jordan a developed country in education and health. Statistics indicate that spending on education in Jordan in the year 2003 amounted to about $13.5 \%$ of GDP. It ranks 80 out of 188 countries on the Human Development Index. Despite the limited resources, the Ministry of Education has developed very advanced national curricula, and many other countries in the region have taken Jordan as a model in developing their educational systems [6]. Recent reforms in the education sector began in Jordan in the early 1990s, as they accelerated the government's insistence on turning Jordan into a regional technology center and an active player in the global economy. In addition, the two main consultative documents that helped shape the national vision and also in identifying directions for education reform initiatives are Jordan Vision 2020 and the 2002 Vision Forum for the Future of Education[10]. According to [16], the Education in Jordan initiative recently received the UNESCO award for the Use of Information and Communications Technology in Education. This pioneering educational project in Jordan's schools is based on leveraging the power of information and technology (IT) through the teaching methods applied and practiced to change the learning environment in schools [8]. Despite the progress enjoyed by the Jordanian education system, some of the current problems in this sector, the most important of which is increasing population growth, particularly young people, still need to be addressed [24]. Fig. 1. Refers to educational stages in the Jordanian Ministry of Education Figure 1: Refers to educational stages in Pre-University Education in the Jordanian Ministry of Education[26]. 


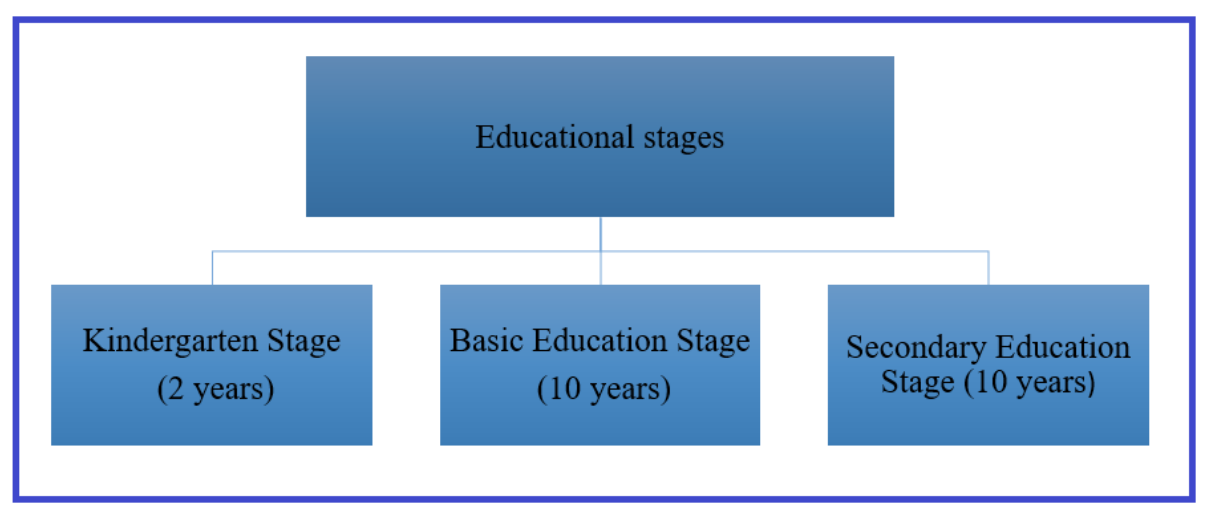

Fig. 1. Educational Stages in Jordanian Ministry of Education.

Basic education is a basis for education, developing capabilities, skills, interests, attitudes, self-inclinations, and guiding students in the light of it. The aims of this stage are to achieve the general goals of education and prepare the citizen in various aspects of his physical, mental, spiritual, emotional and social personality[30].

\subsection{Differentiated instruction (DI)}

The necessity to understand students learning styles is increasing with the invitation for cooperative learning in heterogeneous classes pointed out there is a gradual decline in the level of students' motivation to learn science across the elementary, and intermediate stages in addition to other educational stages[22]. Hence, it has become recognized that science learning for all categories of students requires employing modern and effective teaching strategies that take into account individual differences between students, their interests, attitudes, needs, and varying skills. With the aim of improving their degree of motivation towards learning science, and helping them to gains basic concepts of science, therefore, enabling them to live as active citizens and able to deal with problems, issues, and difficulties correctly[7]. The researchers agree that the problems of the low degree of motivations towards learning science among students are closely related to the nature of science curricula and their traditional teaching strategies that do not consider and concern students' readiness interests, Attitudes' and individual needs. Therefore, it does not provide them with meaningful learning opportunities in science $[12,14,19,57]$. According to[35], that students can achieve a deeper understanding of the sciences topics if teaching strategies diversify to enhance opportunities for scientific understanding and their involvement in activities that require a high degree of mental focusing in a way that satisfies their curiosity and interests. Students differ among themselves and that they do not learn at the same degree or level due to the phenomenon of individual differences among them [55]. Moreover, [1]pointed out, that successful teachers understand the differences between students' as a result of environmental or genetic factors. Thus, they recognize that they are different in their ability to understand science topics and concepts. Thus, differentiation is a main and important issue currently in learning $[6,58]$. According to[29], DI strategy may be the 
best suitable method for dealing with different abilities between students. The DI strategy is considered one of the most modern important and effective strategies that take into account individual differences between students, their interests, attitudes, needs, and varying skills. It is defined also as a strategy that shows and cares about the different educational capabilities of students [19]. Also, DI strategy is a modern strategy that helps learners with varied educational requirements and teaching methods master the same difficult educational content[9, 55]. Moreover, it is a trying to meet the learning needs of a single student or small group of students rather than the more traditional method of teaching the classroom as if it were exactly the same for all the students[37, $42,49,51]$. Additionally, it is also described as teaching philosophy that allows instructors to adapt learning to student differences, like their readiness to learn, levels of thinking, educational preferences, Interests, and Attitudes[37]. Furthermore, [55] defined it as a modern trend in learning that responds to the individual and diverse needs of students, so that balance is strengthened in classroom applications to ensure content learning for all levels of students in ways consistent with their abilities. According to [54], teachers can differentiate the content which means what is taught, the process which means how it is taught, the product which means how learning is evaluated and, according to students, which means differentiating between students through readiness, interest and learning profile, see Figure 2.

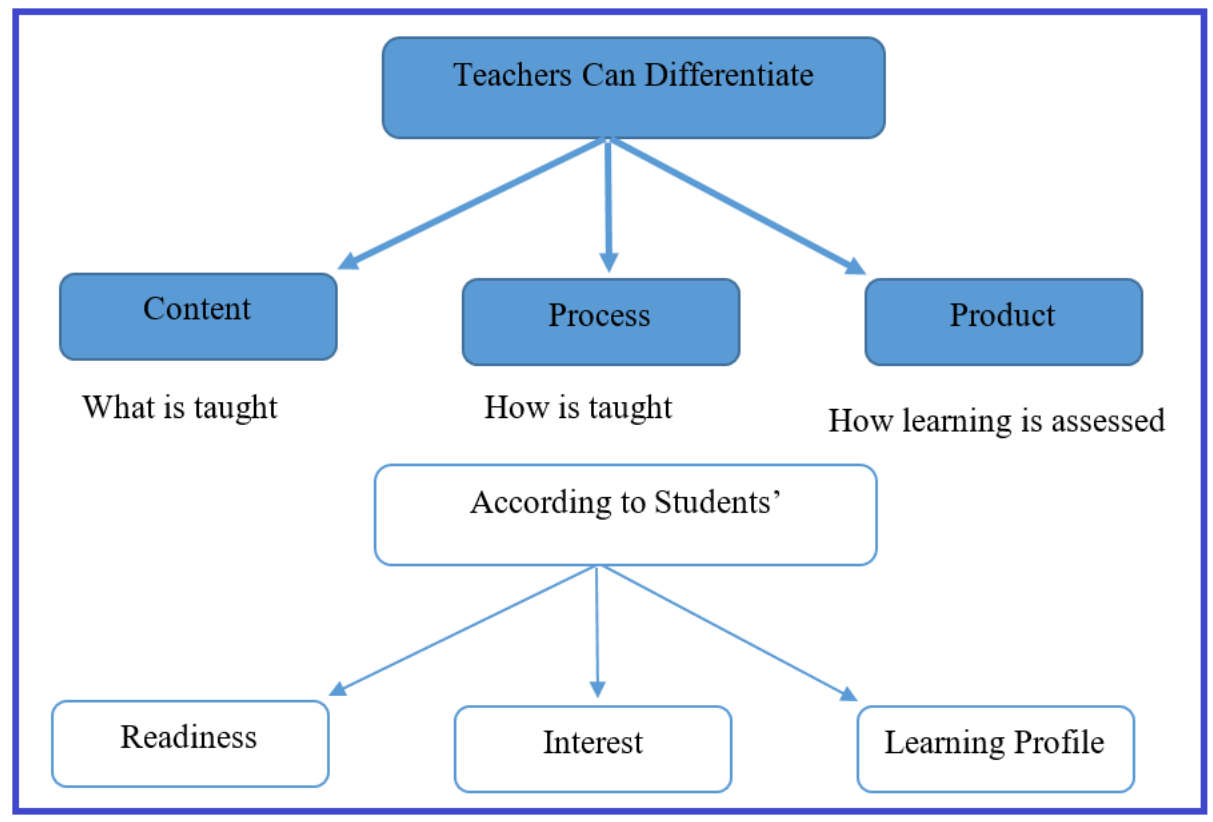

Fig. 2. 


\subsection{Principles and characteristics Differentiated instruction}

The main principles of DI according to [17] as seen below:

- Instructors will not be in a situation utilizing one method of teaching that suits all needs of every learner.

- All learners are involved in substantial and meaningful work or tasks.

- Instructors and learners are working closely to guarantee ongoing engagement and challenge for each learner.

- The instructor schedules time, place, and activities that will utilize for his students in the classroom.

- It provides a learning environment appropriate to all learners, learners have various prior backgrounds, and thus instructors should distinguish and recognize to suit all these backgrounds.

- Differences between the students offer teachers the ability to differentiate instruction.

- Students can know more when they get appropriate support.

- Flexible grouping containing whole-class instruction, pairs, selective groups of learners, selected groups of instructors and randomly of groups

- If students link their personal interests and attitudes with the curriculum, this will lead them to better achievement.

- Instructors understand the differences between the students.

- All learners are engaged in productive work.

The DI strategy has a number of characteristics that are demonstrated in the Fig.3 $[20,53,59]$ :

\section{Characteristics of DI strategy}

-Allows students to be more nearer to the curriculum.

- Makes students motivated and more engaged to learn.

-Ensures equality between students'.

- Simplify and enhances the learning process for learners.

- Helps students comprehend the assessment process better and faster.

- Introduction of new academic learning methods for students.

- Promotes the personality-confidence of students'.

- Motivates individual responsibility among students' in the schoolroom.

- Motivation is recognized via learners' attention themselves.

-It provides various activities and is available to students' according to their

readeness, abilities and interests.

-It allows teachers to provide all students with different teaching methods.

Fig. 3. Characteristics of DI strategy.

Some studies like[13, 59, 60] revealed that the correct application of DI strategy showed improvement in students' achievement and performance for the primary and intermediate stage education. 


\subsection{Traditional schoolroom vs. Differentiated schoolroom}

Researchers [17, 57]have made some differences between DI and traditional learning. Table 1 illustrates these comparisons:

Table 1. Differences between DI and Traditional Instruction.

\begin{tabular}{|l|l|l|}
\hline \multicolumn{1}{|c|}{ Difference item } & \multicolumn{1}{|c|}{ Traditional Learning } & \multicolumn{1}{c|}{ Differentiated instruction (DI) } \\
\hline Teaching Methods & $\begin{array}{l}\text { All learners get one form of teach- } \\
\text { ing }\end{array}$ & $\begin{array}{l}\text { learners receive several different } \\
\text { forms of teaching methods }\end{array}$ \\
\hline Differences between learners & $\begin{array}{l}\text { They have been ignored and ne- } \\
\text { glected }\end{array}$ & $\begin{array}{l}\text { It is taken care of and studied before } \\
\text { the session starts to teach }\end{array}$ \\
\hline Content of teaching & $\begin{array}{l}\text { Single instructional content to all } \\
\text { students }\end{array}$ & It uses many learning content \\
\hline $\begin{array}{l}\text { Intelligence } \\
\text { between learners }\end{array}$ & Seldom regarded & According to multiple intelligences \\
\hline Evaluation time & $\begin{array}{l}\text { Utilized at the end of the chapter, } \\
\text { unit, monthly or term }\end{array}$ & Continuing evaluation \\
\hline Instruments for evaluation & $\begin{array}{l}\text { A single evaluation instrument is } \\
\text { utilized }\end{array}$ & $\begin{array}{l}\text { Multiple evaluation instruments are } \\
\text { Utilized }\end{array}$ \\
\hline The opportunities for learning & Seldom given & $\begin{array}{l}\text { Usually } \\
\text { given }\end{array}$ \\
\hline
\end{tabular}

\subsection{Differentiated instruction strategy types in school classrooms}

According to[57], a number of strategies help to differentiate between students in the teaching process and in the classroom, summarized in Fig. 4.

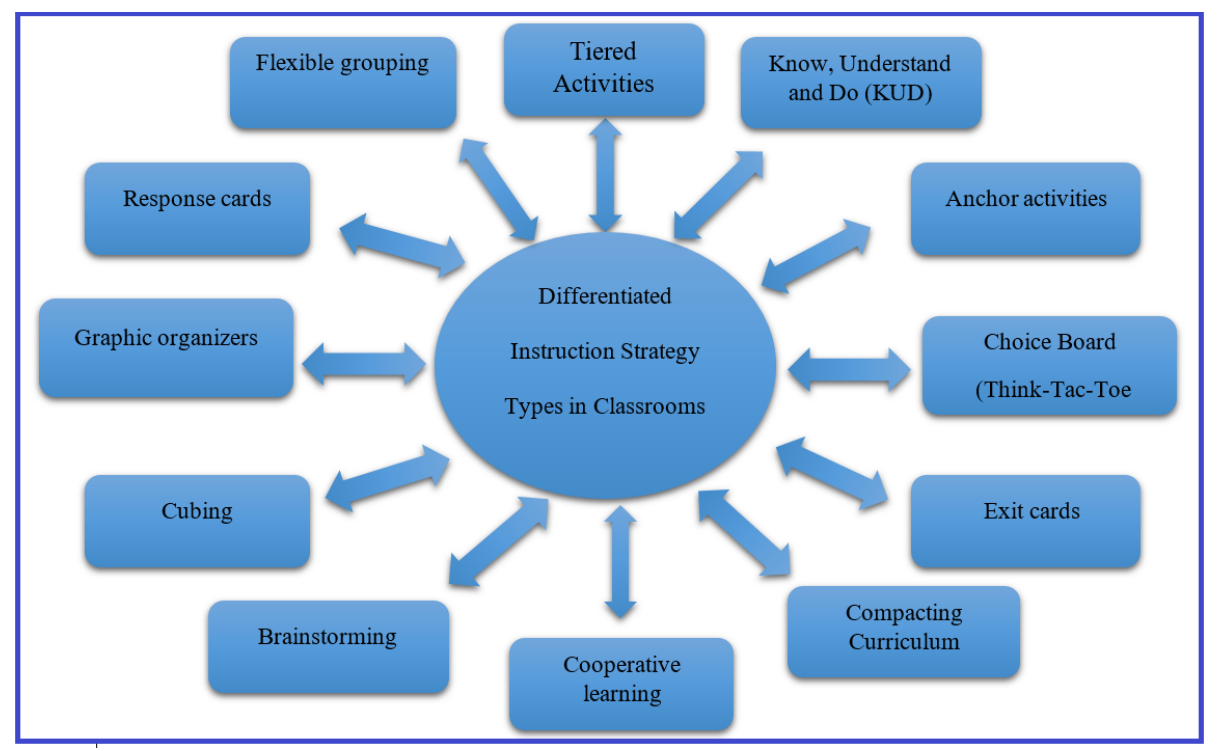

Fig. 4. Differentiated instruction strategy types. 


\subsection{Previous studies}

So many studies on the use of DI strategy in the learning sector were implemented. Findings from those studies showed that the academic achievement of learners who have been educated by utilizing the DI approach has been increased in a positive way compared to the conventional approach. The findings also revealed that the assessment and evaluation of their achievement in the exams were in the favor of the empirical group learners because it became clear that there is a statistically significant variation among the degrees of the empirical group students and the control group students. Which confirms that the DI strategy has a significant effect on learners' achievement $[4$, $8,11,23,28,41,52]$ With regard to studies to determine the impact of a differentiated teaching strategy on science education for students and its effect on student achievement, these studies also showed the positive impact of differentiated instruction DI strategy on increasing student achievement in science topics[18, 36, 45, 47, 48] . On the other hand, other studies revealed that despite the widespread recognition that the differentiation instruction strategy represents an important educational approach for students' and is concerned with taking into account their individual differences, their tends, interests, and readiness to learn. The exact relationship between differentiation and student learning and its impact on their academic performance and achievement, it still little understood and distinguished which needs more exploration and research [34]. Likewise, [3], have pointed out that it is difficult to assess the potential impact of differentiated instruction on student performance, since the impacts of differentiation may vary in each educational institution due to different variables like the educational environment, teachers 'ability to implement differentiated learning, and teachers 'ability, experience, and competence to implement the differentiated learning strategy. In addition, [50], have point out that learners who have learned through differentiated instruction do not experience poorer academic performance, but strong positive results and evidences from differentiated instruction still need to be identified.

\section{Study problem and its questions}

Improve the academic performance of students with varying achievements and giving greater opportunities to the learning of all students according to their different mental abilities and their willingness to learn, their interests, and desires is a primary goal according to modern theories in education such as constructivism. The science topics learning needs good and modern strategies in order to be our students to get more understanding and academic achievement. Thus, the challenge for teaching subjects like science and mathematics is the ability of teachers 'ability to choose the best instructional strategies that take into account students' needs, abilities, readiness, and interests, and thus take into account their individual differences.[27], pointed out that the weaker achievement students on science, mathematics is a troubling process for education experts and supervisors, and it might represent a crisis in the learning and teaching process that reflects on the quality of education. Furthermore,[21], also concluded that teachers should seek to find effective learning and teaching strategies focused on the needs of students, making them more motivated and engaged to the classroom. According to the 
Constructivism Theory, Science and Mathematics, the concepts in the textbooks no longer concentrated on memorizing and recalling the facts, but actually concentrated on a deep understanding of the concepts, rules, curves, numbers, and figures and related them in life. This study, therefore, came to look for the reply to the following:

RQ1. What is the effect of using of the differentiated instruction strategy on Students' Achievement in Science course at intermediate Stage?

RQ2. What are the Students' attitudes in the empirical group towards using differentiated instruction strategy in teaching science?

RQ3: Does the attitudes of students of the empirical group towards using differentiated instruction strategy in teaching science vary according to Gender?

\subsection{Study purpose}

The purpose of this study was to carry out an examination of the impact of the use of the DI strategy on student achievement at the intermediate level, as well as the attitudes of learners, in the empiric group towards the DI strategy.

The significance of the study

The significance of this study is indicated as shown in:

- Teachers' should face the problems of moving from conventional teaching methods to learning strategies that address the varied needs of the students'.

- The findings of the study may confirm that the objectives of the standards-based curriculum like science and mathematics need strategies for learning that take into account individual differences between students such as DI Strategy.

- The findings of the study may benefit educational experts and curricula, developers, in developing plans that will contribute to the improvement of science learning.

- The findings of the study could add to the literature that supports the use of DI and concludes that there is a positive impact of DI on student achievement.

- The findings of the study may benefit the teacher educators and educational experts with a comparative study of differentiated instruction and conventional learning.

- This study is considered complementary to studies that dealt with DI and their link to curricula and education.

\subsection{Study Terms}

- Differentiated instruction: Defined by Furthermore, [55], as a modern trend in learning that responds to the individual and diverse needs of students, so that balance is strengthened in classroom applications to ensure content learning for all levels of students in ways consistent with their abilities.

- Students' achievement: The knowledge that the learner obtains to adapt to the learning environment and work environment through a school program or a school curriculum[5].

- Effect: The effect is a shift that occurs when anything occurs: an activity, a circumstance, even a condition arising from a specific cause. 
- Attitudes: Attitude is a psychological construct, a cognitive and a passion that characterizes a person with a negative or positive feeling towards something or a fact (Richard, 2016).

\section{$4 \quad$ Methodology}

\subsection{Participants}

The Participants in the present study were 483 students (male 135 and female 125) studies were randomly selected from 8 intermediate stage schools in the Marka Education Zone in the north of Amman City, Jordan during the academic year 2019/2020. Table 2 shows the demographic information for the participants in the current study.

Table 2. Demographic information of participants

\begin{tabular}{|l|c|c|c|c|}
\hline \multirow{2}{*}{ Study Group } & \multirow{2}{*}{$\begin{array}{c}\text { Number of } \\
\text { Students }\end{array}$} & \multicolumn{2}{c|}{ Gender } & \multirow{2}{*}{ Percentage (\%) } \\
\cline { 3 - 5 } & & Female & Male & \\
\hline Experimental & 244 & $123(50.4 \%)$ & $121(49.6 \%)$ & $50.5 \%$ \\
\hline Control & 239 & $119(49.8 \%)$ & $120(50.2 \%)$ & $49.5 \%$ \\
\hline Total & \multicolumn{3}{|c|}{483} & \\
\hline
\end{tabular}

\subsection{Study Approach}

Due to its appropriateness for the study's objectives, a quasi-experimental approach was used. In the current study, the researchers utilized two groups of students (Empirical group 244 students) and (control group 239 students). The topics of Unit 3 (Matter) of the Eighth Grade Science textbook were taught to the students in the control group using conventional teaching, while in the empirical group the students were taught the same topics of a science textbook by the differentiated instruction. That means that during the first term of the 2019/2019 scholar year, the two groups studied the same topics. Teaching topics are listed in Table (3).

Study tools. The investigators study analyzed prior literature and studies pertaining to the study, such as studies of $[4,18,23,31]$. Therefore, this study depends mainly on two data instruments: Achievement exam, and questionnaire, which are in detail as the following:

Achievement test. The researchers formulated a performance test to examine the effect of using the DI strategy on student achievement in the course of science. The exam was designed in line with Bloom 's cognitive domain taxonomy[25]. Moreover, a specification table for this exam was designed (see Table 4). The test consisted, in its finished product, of 20 multiple-choice questions. The question item earned one mark for a correct response and zero for a wrong response. The highest test scores were 20, and the test time was 80 minutes. 
Table 3. The learning topics in the unit of Matter

\begin{tabular}{|c|c|c|c|}
\hline Name of the unit & Chapter & Topics & Pages \\
\hline \multirow{11}{*}{ Matter } & \multirow{6}{*}{$\begin{array}{l}\text { Structure of } \\
\text { Matter }\end{array}$} & Lesson 1: The Structure of Atoms & $85-91$ \\
\hline & & Lesson 2: Atomic Number and Mass Number & $92-94$ \\
\hline & & Lesson 3: Electronic Distribution of Atoms & 95- 97 \\
\hline & & Lesson 4: Periodic Table & $98-102$ \\
\hline & & Lesson 5: Stability of Atoms & $103-107$ \\
\hline & & Chapter Review & $108-109$ \\
\hline & \multirow{5}{*}{$\begin{array}{l}\text { Chemical } \\
\text { Bond and } \\
\text { Chemical } \\
\text { Equation }\end{array}$} & Lesson 1: Ionic Bond. & $110-114$ \\
\hline & & Lesson 2: Chemical Formulas for Ionic Compounds. & $115-119$ \\
\hline & & Lesson 3: Chemical Equations. & $120-126$ \\
\hline & & Chapter Review & $127-128$ \\
\hline & & Unit Review & $129-132$ \\
\hline \multicolumn{3}{|c|}{ Total number of pages } & $85-110$ \\
\hline
\end{tabular}

Table 4. Specifications for the test of the topics

\begin{tabular}{|l|c|c|c|c|c|}
\hline \multicolumn{1}{|c|}{ Topics } & $\begin{array}{c}\text { Number of } \\
\text { lectures }\end{array}$ & $\begin{array}{c}\text { Relative } \\
\text { weight of } \\
\text { topics }\end{array}$ & $\begin{array}{c}\text { LOT ques- } \\
\text { tions }\end{array}$ & $\begin{array}{c}\text { HOT ques- } \\
\text { tions }\end{array}$ & $\begin{array}{c}\text { Total of } \\
\text { questions }\end{array}$ \\
\hline The Structure of Atoms & 2 & 8.0 & 2 & 0 & 2 \\
\hline Atomic Number and Mass Number & 3 & 12.0 & 1 & 1 & 2 \\
\hline Electronic Distribution of Atoms & 3 & 12.0 & 2 & 1 & 3 \\
\hline Periodic Table & 4 & 16.0 & 2 & 1 & 3 \\
\hline Stability of Atoms & 3 & 12.0 & 2 & 1 & 3 \\
\hline Ionic Bond. & 3 & 12.0 & 2 & 1 & 3 \\
\hline $\begin{array}{l}\text { Chemical Formulas for Ionic Com- } \\
\text { pounds. }\end{array}$ & 3 & 12.0 & 2 & 0 & 2 \\
\hline Chemical Equations. & 4 & 16.0 & 1 & 1 & 2 \\
\hline Total & $\mathbf{2 5}$ & $\mathbf{1 0 0 . 0}$ & $\mathbf{1 4}(\mathbf{7 0} \%)$ & $\mathbf{6}(\mathbf{3 0} \%)$ & $\mathbf{2 0}(\mathbf{1 0 0} \%)$ \\
\hline
\end{tabular}

*LOT $=$ lower order thinking: remembering, understanding, and applying.

*HOT $=$ higher order thinking: analyzing, evaluating, and creating.

Validity and Reliability of achievement test. The achievement test was verified by submitting it, in its initial form, as a valid virtual test method; to members of the teaching staff at universities whose doctoral and master's degree holders in curricula and teaching methods. We removed a few of the questions and introduced others as recommended and suggested, even the test became valid. In addition, the researchers used the test-retest way to check the reliability of the achievement test. We carried out the test on a sample from outside the sample of the study. It was re-applied on the same students' sample two weeks after first applying the test. Afterward, the Pearson correlation coefficient between the two applications was determined, in which the total reliability coefficient (0.834) was deemed appropriate for this study purpose.

Questionnaire. In order, to explorer, the students' attitudes of the empirical group about the utilize of the DI strategy during their learning Science topics. A Likert-scale based questionnaire was administered. The structure of the questionnaire was com- 
posed of two parts. The first part of the questionnaire included the learners' basic information. In the second part of the questionnaire, there were 20 elements to explore the attitude students toward the utilize of the DI strategy during their learning Science topics. The Likert scale with the range period for each point was as follows: the point (1) represents Very little with range period (1.00-1.80) and, (2) represents little with range period (1.81-2.60), (3) represents Moderate with range period (2.61-3.40), (4) represents High with range period (3.41-4.20), and (5) represents Very High with range period (4.21-5.00).

The validity and reliability of Questionnaire. To test the validity of the questionnaire was given to a number of educational specialists of curricula and method of teaching science from multi academic universities at Jordan, who then provided written feedback, about the items of the questionnaire that researchers can improve and amend to ensure that the study goal is achieved. The educational specialists' comments and modifications suggested were taken from the deletion, amendment, and addition, and as a result, the questionnaire after modification was consisted of (20) items, to achieve the objective of the research. Likewise, the reliability of internal consistency was measured utilizing Cronbach's Alpha. Table (5) shows the Cronbach's Alpha reliability coefficients for each of the questionnaire items, in addition to the total Cronbach's Alpha reliability coefficient which it is the value (0.907) signifying a good level to application.

Equivalence of experimental and control groups (Pre-test). To examine the equivalence of participants between the learners of the two groups studied. The researcher utilized a t-test to compare the results of the pretest of the topics of the science textbook unit, before implementing the DI strategy as shown in Table 6.

Table 5. Cronbach's Alpha reliability coefficients for each of the questionnaire items.

\begin{tabular}{|c|c|c|c|c|c|}
\hline No. & Item & Cronbach's Alpha & No. & Item & Cronbach's Alpha \\
\hline 1 & Q1 & 0.907 & 11 & Q11 & 0.905 \\
\hline 2 & Q2 & 0.903 & 12 & Q12 & 0.907 \\
\hline 3 & Q3 & 0.902 & 13 & Q13 & 0.904 \\
\hline 4 & Q4 & 0.902 & 14 & Q14 & 0.905 \\
\hline 5 & Q5 & 0.901 & 15 & Q15 & 0.904 \\
\hline 6 & Q6 & 0.900 & 16 & Q16 & 0.901 \\
\hline 7 & Q7 & 0.899 & 17 & Q17 & 0.902 \\
\hline 8 & Q8 & 0.900 & 18 & Q18 & 0.898 \\
\hline 9 & Q9 & 0.908 & 19 & Q19 & 0.904 \\
\hline 10 & Q10 & 0.906 & Q20 & 0.900 \\
\hline \multicolumn{2}{|c|}{ Total } & & \\
\hline
\end{tabular}

Table 6. T-test of pre-test results of the two study groups

\begin{tabular}{|l|c|c|c|c|c|c|}
\hline \multicolumn{1}{|c|}{ Group } & $\mathbf{N}$ & Mean & $\begin{array}{c}\text { Std deviation } \\
\text { (SD) }\end{array}$ & T. value & Sig. (tailed) & Sig. level \\
\hline Pre-control & 239 & 10.36 & 2.26 & \multirow{2}{*}{0.307} & 0.759 & Significant \\
\cline { 1 - 4 } Pre-experimental & 244 & 10.30 & 2.09 & & \\
\hline Statistically significant at $(\mathrm{p}<0.05)$ &
\end{tabular}


As presented in Table 6, given that the $\mathrm{p}(0.759)$ extracted is larger than 0.05 , the test is not significant at a scale of 0.05 . This proves that there is no significant variation between the two study groups. This detects that the empirical group and the control group were identical before the implementation of the quasi-experimental method.

Statistical processing methods. The investigator used the SPSS software program to analyze the study data by performing a descriptive analysis, such as frequency calculation, average, and standard deviation (SD), including independent sample test (T-test).

\section{$5 \quad$ Findings}

\subsection{Findings of the study attributed to Question 1.}

RQ1: What is the effect of using of the differentiated instruction strategy on Students' Achievement in Science course at intermediate Stage? The difference between the mean of students' scores in the empirical group that taught by the DI strategy and the students of the control group that that taught by tradition learning way was calculated. In addition, a t-test was used for two independent samples as presented in Tables 7 and 8 .

Table 7. Means and SD of post-test results.

\begin{tabular}{|l|c|c|c|}
\hline \multicolumn{1}{|c|}{ Group } & N & Mean & SD \\
\hline Experimental & 244 & 16.86 & 1.70 \\
\hline Control & 239 & 11.50 & 1.64 \\
\hline
\end{tabular}

As seen in Table (7), the results refer that the students of the empirical group who were taught by the DI strategy were the different comparing by the control group. As appear in Table 8 . The empirical group grades were different $(\mathrm{M}=16.86, \mathrm{SD}=1.70)$ from the control group of students $(\mathrm{M}=11.50, \mathrm{SD}=1.64)$.

Table 8. The independent sample t-test of post-test.

\begin{tabular}{|l|c|c|c|c|c|c|}
\hline & $\begin{array}{c}\text { Levene's Test for } \\
\text { Equality of Vari- } \\
\text { ances }\end{array}$ & \multicolumn{5}{|c|}{ t-test } \\
\hline & $\boldsymbol{F}$ & Sig. & $\boldsymbol{t}$ & $\boldsymbol{d f}$ & Sig.(2-tailed) & Mean Difference \\
\hline & 3.533 & 0.061 & 35.291 & 481 & 0.000 & 5.3627 \\
\hline Equal variances assumed & & & 5.620 & 480.849 & 0.000 & 5.3627 \\
\hline $\begin{array}{l}\text { Equal variances not as- } \\
\text { sumed }\end{array}$ & & & & & & \\
\hline
\end{tabular}

As appear in Table 8, given that the p-value $(0.000)$ is lower than 0.05 , this confirms there are significant differences at the significance level of 0.05 , which implies that there is a substantial difference between the two groups of participants. As appear in Table 5, given that the p-value $(0.000)$ is lower than 0.05 , this confirms there are significant differences at the significance level of 0.05 , which implies that there is a substantial difference between the two groups of participants in favor of the students of the empirical group. This implies based on the results of this T-test, it may be indicated that 
a differentiated teaching strategy is used of the DI strategy has a positive effect on Students' Achievement in Science course at intermediate Stage.

\subsection{Findings of the study attributed to Question 2}

The question was: What are the students' attitudes in the empirical group towards using differentiated instruction strategy in teaching science? Average scores and standard deviations have been computed to address the second research question. Responses of the empirical group students to items $1-25$ of the questionnaire related to attitudes of female students towards the use of video recording in microteaching sessions, as presented in Table 9.

Table 9. Means and SD of the empirical group students' responses regarding their attitudes towards using differentiated instruction strategy in teaching science.

\begin{tabular}{|c|c|c|c|c|}
\hline No. & Item & Mean & SD & Degree \\
\hline 1 & Differentiated instruction meets my science learning needs. & 3.99 & 1.29 & High \\
\hline 2 & My academic achievement in topics science become better than before. & 3.65 & 1.28 & High \\
\hline 3 & $\begin{array}{l}\text { I got more motivated to learn science topics through the differentiated in- } \\
\text { struction strategy. }\end{array}$ & 3.48 & 1.21 & High \\
\hline 4 & $\begin{array}{l}\text { My teacher has taken into account the individual differences between the } \\
\text { students and me during the differentiated instruction. }\end{array}$ & 3.51 & 1.23 & High \\
\hline 5 & I feel that science subject is boring and difficult to learn & 3.23 & 1.40 & Moderate \\
\hline 6 & I like to learn science topics by using differentiated learning strategy. & 4.03 & 1.03 & High \\
\hline 7 & I feel I am doing my lesson activities with ease & 3.75 & 1.31 & High \\
\hline 8 & $\begin{array}{l}\text { I feel that differentiated instruction provides me with an opportunity to } \\
\text { learn equally with students in my class. }\end{array}$ & 3.95 & 1.14 & High \\
\hline 9 & The activities that give us by a teacher during class are fun and engaging. & 3.90 & 1.16 & High \\
\hline 10 & $\begin{array}{l}\text { Using differentiated instruction strategy in the class has helped me aca- } \\
\text { demically. }\end{array}$ & 3.74 & .89 & High \\
\hline 11 & $\begin{array}{l}\text { Using differentiated instruction strategy in my class has helped to build } \\
\text { my confidence. }\end{array}$ & 3.66 & 1.11 & High \\
\hline 12 & $\begin{array}{l}\text { Using differentiated instruction strategy in my class has enhanced my as- } \\
\text { sessment grade in science. }\end{array}$ & 3.55 & .88 & High \\
\hline 13 & $\begin{array}{l}\text { I feel during differentiated instruction have enough time to finish exer- } \\
\text { cises and tasks of science. }\end{array}$ & 3.82 & 1.17 & High \\
\hline 14 & I feel I am become being more interested in my science scores. & 3.54 & 1.30 & High \\
\hline 15 & I enjoy the review activities we do in science class. & 3.28 & 1.28 & Moderate \\
\hline 16 & $\begin{array}{l}\text { The activities we do in science class by differentiated instruction strategy } \\
\text { help me learn. }\end{array}$ & 3.95 & 1.10 & High \\
\hline 17 & $\begin{array}{l}\text { The activities we do by differentiated instruction strategy are fun and } \\
\text { challenge. }\end{array}$ & 3.84 & 1.03 & High \\
\hline 18 & $\begin{array}{l}\text { I would probably understand well in science when I learn it by differenti- } \\
\text { ated instruction strategy. }\end{array}$ & 3.71 & 1.13 & High \\
\hline 19 & $\begin{array}{l}\text { I believe that science content topics have been presented to us according } \\
\text { to our capabilities and interests. }\end{array}$ & 3.70 & 1.12 & High \\
\hline 20 & I feel more interested in learning science topics & 3.68 & 1.11 & High \\
\hline \multicolumn{2}{|r|}{ Total } & 3.70 & 1.16 & High \\
\hline
\end{tabular}


As illustrated in Table 9, the questionnaire was composed of 20 items. The findings mentioned in Table 9 demonstrate that the general arithmetic mean (3.70) and SD (1.16) of all questions related to the use of using DI strategy in teaching science was at the High level from the perspective of students of the empirical group. That implies the findings are positive to utilize DI strategy in teaching science. Table 9 also demonstrates that the participants' answers to Q-6 (I like to learn science topics by using differentiated learning strategy.) are compatible and suitable to students with the highest average (4.03) and with High level. Also, Q-1 (Differentiated instruction meets my science learning needs.) came in second, also at High level with a mean value of (3.99). Interestingly, both the Q-8 (I feel that differentiated instruction provides me with an opportunity to learn equally with students in my class.) and the Q-16 (The activities we do in science class by differentiated instruction strategy help me learn.) had an elevated mean degree of agreement with the same average values of (3.90) at a high level. Furthermore, the smallest Mean (3.23) was acquired was acquired for Q- 5 (I feel that science subject is boring and difficult to learn) appearing a Moderate level. Likewise, a Moderate agree level has also been demonstrated for Q-15, with average value of (2.28). Furthermore, it is also clear from the students ' answers as seen in the table (9), all other questions scored came at a High level.

\subsection{Findings of the study attributed to Question 3}

The question was: Does the attitudes of students of the empirical group towards using differentiated instruction strategy in teaching science vary according to Gender?

In order to answer the third question, the independent sample test (T) was used to find out the significance of the differences between averages towards the use of DI from the perspective of students, according to gender (see Table 10).

Table 10. Means and SD of the students' responses according to gender variable.

\begin{tabular}{|c|c|c|c|c|c|c|}
\hline Gender & N & Mean & SD & T. Value & Sig. (tailed) & Sig. level \\
\hline Female & 121 & 3.356 & 0.782 & \multirow{2}{*}{0.304} & 0.762 & Not Significant \\
\hline Male & 123 & 3.328 & 0.684 & & \\
* Statistically significant at $(\mathrm{P} \leq 0.05)$
\end{tabular}

The findings recorded in Table 10 illustrate that the observed $\mathrm{p}(0.762)$ is larger than 0.05 . Thus, the test in 0.05 scale is not significant, suggesting that there is no significant difference in attitudes of students of the empirical group towards using DI strategy in teaching science vary according to Gender variable

\section{Discussion}

The findings achieved relating the first research question, regarding the effect of the use of the Differentiated instruction strategy on Students' Achievement in Science course at intermediate Stage. Stated that there was a significant difference among learners in the experimental and control group in favor of learners in the empirical group. The average score of students in the empirical group who used the DI strategy was 
16.86, compared to 11.50 for the control group which taught by traditional learning (Tables 7 and 8). Additionally, as seen in Table 8, as the obtained p-value (0.000) is less than 0.05 , this implies existence significant differences at the significance level of 0.05 , which confirmed existence a significant difference between the two groups of students. This indicates that using the DI strategy had a positive effect on Students' Achievement in Science course. The researchers attribute the reason why the empirical group students outperform the control group students because the DI strategy focuses and guides students towards performing the most of their abilities through the various activities that it provides to them while learning science subjects. The findings achieved in connection to the second study question, related to the attitudes of students of the empirical group towards the use of differentiated instruction strategy in teaching science. The effect of utilize of DI strategy in educating science showed that the attitudes of students of the empirical group came at a High level (Table 9). The mean for all questionnaire questions (1-20) was 3.70, with an SD of 1.16. The researchers attribute the reason for this to the fact that differentiated learning increases the motivation of learning among students and takes into account their interests and desires, in addition to that it provides them with different alternatives in thinking thus contributes to increasing students' interest in the science course. It also helps in establishing positive connections with their peers in the schoolroom. The third research question focused on determining whether the attitudes of students of the empirical group towards using differentiated instruction strategy in teaching science vary according to Gender. Our findings illustrated in Table 10 showed that students' of the empirical group do not vary according to the variable of gender did not show differences between them with regard to this variable. Results are consistent with previous studies[4, 11, 23, 28, 47, 52]. The findings of these studies have shown that the performance and achievement of learners who have been educated by utilizing the DI strategy have been increased in a positive way compared to the conventional approach. Nevertheless, the findings of the study were not consistent with the findings of other studies [38, 40, 43, 46]. The results of these studies found that there is no positive effect of the DI strategy on students' academic achievement in addition the students may behave become nervous to learn the science topics.

\section{Conclusion}

Education and learning in Jordan are one of the best education systems in the countries of the world. Learning plays a pivotal and essential role in Jordanian society's life and culture. Thus, this study aimed at investigating the effects of the use of the Differentiated instruction strategy on students' achievement in a science course at the intermediate stage and their attitudes towards it. which will be expected to increase their understanding of topics science in and prepare them as students having the capabilities to solving problems in their life. The finding of this study revealed that using the DI strategy had a positive effect on increasing students' achievement in a science course at the intermediate stage. Where the data analyses confirmed that there were statistical 
differences between the experimental and the control groups, in the benefit of the empirical group, were also more positive towards the use of DI strategy. Moreover, results referred also that there is no significant difference in attitudes of students of the empirical group towards using DI strategy in teaching science vary according to Gender variable. study is significant because it considered one of the most modern and advanced teaching strategies, which many countries have started using and applying to take into account the different needs, inclinations, and interests of students, and the differences between their levels in understanding.

\section{Recommendations}

The study recommended the following based on the results:

- Interest in applying the DI strategy in teaching science curricula and other textbooks.

- Developing and improving science curricula textbooks according to modern teaching strategies, such as DI strategy.

- Carrying out similar studies on other textbooks, such as mathematics and other textbooks.

\section{$9 \quad$ References}

[1] S. M. Aguillon, G.-F. Siegmund, R. H. Petipas, A. G. Drake, S. Cotner, and C. Ballen, "Gender differences in student participation in an active-learning classroom," CBE-Life Sciences Education, vol. 19, no. 2, p. ar12, 2020. https://doi.org/10.1187/cbe.19-03-0048

[2] A. H. Alaidi, O. H. Yahya, and H. T. S. AlRikabi, "Using modern education technique in Wasit university," International Journal of Interactive Mobile Technologies, Article vol. 14, no. 6, pp. 82-94, 2020. https://doi.org/10.3991/ijim.v14i06.11539

[3] F. Alanazi, "The effectiveness of the 4MAT teaching approach in enhancing conceptions of electricity in physics for female students in the Kingdom of Saudi Arabia," Journal of Turkish Science Education ,vol. 17, no. 2, pp. 271-288, 2020. https://doi.org/10.36681/tused.2020.26

[4] M. Aliakbari and J. Khales Haghighi, "Impact of differentiated instruction strategies and traditional-based instruction on the reading comprehension of Iranian EFL students," Journal of Research in Applied Linguistics, vol. 5, no. 1, pp. 109-129, 2014.

[5] S. Aloraini and Translation, "The impact of using multimedia on students' academic achievement in the College of Education at King Saud University," Journal of King Saud University-Languages and Translation, vol. 24, no. 2, pp. 75-82, 2012. https://doi.org/10.1016/j.jksult.2012.05.002

[6] N. S. Alseelawi, E. K. Adnan, H. T. Hazim, H. Alrikabi, and K. Nasser, "Design and Implementation of an E-learning Platform Using N-Tier Architecture," International Journal of Interactive Mobile Technologies, vol. 14, no. 6, pp. 171-185, 2020. https://doi.org/10.3991/ijim.v14i06.14005

[7] A. Barton, "Crafting multicultural science education with preservice teachers through service-learning," Journal of Curriculum Studies, vol. 32, no. 6, pp. 797-820, 2000. https://doi.org/10.1080/00220270050167189 
Paper-Impact of Using the Differentiated Instruction (DI) Strategy on Student Achievement in an ...

[8] M. Beecher and S. Sweeny, "Closing the achievement gap with curriculum enrichment and differentiation: One school's story," Journal of advanced academics, vol. 19, no. 3, pp. 502530, 2008. https://doi.org/10.4219/jaa-2008-815

[9] K. Brentnall, "Believing everyone can learn: Differentiating instruction in mixed ability classrooms," College of Saint Elizabeth, 2016.

[10] K. Brown, M. Davis, C. Elrod, E. Hill, D. Jordan, and E. Leadership, "Coaching Initiative for Beginning Teachers (BT): Lessons Learned from One District's BT Support Program," Journal of Organizational \& Educational Leadership, vol. 6, no. 2, p. 2, 2020.

[11] S. Castle, C. B. Deniz, M. Tortora, and u. society, "Flexible grouping and student learning in a high-needs school," Education and urban society, vol. 37, no. 2, pp. 139-150, 2005. https://doi.org/10.1177/0013124504270787

[12] P. Cavas, "Factors affecting the motivation of Turkish primary students for science learning," Science education international, vol. 22, no. 1, pp. 31-42, 2011.

[13] D. De Neve, G. Devos, and S. Improvement, "The role of environmental factors in beginning teachers' professional learning related to differentiated instruction," vol. 27, no. 4, pp. 357-379, 2016. https://doi.org/10.1080/09243453.2015.112263

[14] D. Al-Malah, H. Th. Salim ALRikabi, "Enhancement of educational services by using the internet of things applications for talent and intelligent schools," Periodicals of Engineering and Natural Sciences (PEN), vol. 8, no. 4, pp. 2358-2366, 2020.

[15] D. Al-Malah , H. TH. ALRikabi, "The Interactive Role Using the Mozabook Digital Education Application and its Effect on Enhancing the Performance of eLearning," International Journal of Emerging Technologies in Learning (iJET), vol. 15, no. 20, pp. 21-41, 2020. https://doi.org/10.3991/ijet.v15i20.17101

[16] M. Elfert, "Lifelong learning in Sustainable Development Goal 4: What does it mean for UNESCO's rights-based approach to adult learning and education?," vol. 65, no. 4, pp. 537556, 2019. https://doi.org/10.1007/s11159-019-09788-z

[17] S. A. Elian and D. A. Hamaidi, "The effect of using flipped classroom strategy on the academic achievement of fourth grade students in Jordan," 2018.

[18] A. M. Ferrier, "The effects of differentiated instruction on academic achievement in a second-grade science classroom," Walden University, 2007.

[19] S. Gangi, "Menomonie, WI Gangi, Suzanna Differentiating Instruction Using Multiple Intelligences in the Elementary School Classroom: A Literature Review Graduate Degree/Major: MS Education," University of Wisconsin-Stout, 2011.

[20] E. Gheyssens, C. Coubergs, J. Griful-Freixenet, N. Engels, and K. Struyven, "Differentiated instruction: the diversity of teachers' philosophy and praxis to adapt teaching to students' interests, readiness and learning profiles," pp. 1-18, 2020. https://doi.org/10.1080/13603116.2020.1812739

[21] K. J. Grimes and D. Stevens, "Glass, bug, mud," Phi Delta Kappan, vol. 90, no. 9, pp. 677680, 2009. https://doi.org/10.1177/003172170909000914

[22] Ö. Güvercin, C. Tekkaya, and S. J. H. Ü. E. F. D. Sungur, "A cross age study of elementary students' motivation towards science learning," vol. 39, no. 39, pp. 233-243, 2010.

[23] A. Hassan, "The effect of DI strategy on the achievement of art education department students in history of arts subject," vol. 27, pp. 5-10, 2016.

[24] K. Hüfner, "UNESCO-United Nations Educational, Scientific and Cultural Organization," in A concise encyclopedia of the United Nations: Brill Nijhoff, 2010, pp. 715-718. https://doi.org/10.1163/ej.9789004180048.i-962.616

[25] I. Hyder, S. Bhamani, and E. Development, "Bloom's taxonomy (cognitive domain) in higher education settings: Reflection brief," vol. 3, no. 2, pp. 288-300, 2016. https://doi.org/10.22555/joeed.v3i2.1039 
[26] W. Jansen and Education, "Gender and the expansion of university education in Jordan," vol. 18 , no. 5, pp. 473-490, 2006.

[27] C. Kea, "Connecting rural African American families with differentiated home learning instruction for their preschoolers," vol. 28, no. 4, pp. 10-20, 2009. https://doi.org/10.1177/875687050902800403

[28] D. Lawrence-Brown, "Differentiated instruction: Inclusive strategies for standards-based learning that benefit the whole class," pp. 34-62, 2004.

[29] B. Logan, "Examining differentiated instruction: Teachers respond," Research in higher education journal, vol. 13, 2011.

[30] A. K. Makarigakis and B. Jimenez-Cisneros, "UNESCO’s contribution to face global water challenges," Water, vol. 11, no. 2, p. 388, 2019. https://doi.org/10.3390/w11020388

[31] Z. K. Mbugua and M. W. Muthomi, "Effectiveness of differentiated instruction on secondary school students achievement in mathematics," 2014.

[32] B. McBride, "Data-driven instructional methods:'One Strategy Fits All'doesn't work in real classrooms," vol. 31, no. 11, p. 38, 2004.

[33] H. Morgan, Issues and Ideas, "Maximizing student success with differentiated learning," The Clearing House: A Journal of Educational Strategies, Issues and Ideas, vol. 87, no. 1, pp. 34-38, 2014. https://doi.org/10.1080/00098655.2013.832130

[34] Q. Mulder, "The effect of differentiated instruction on student mathematics achievement in primary school classrooms," University of Twente, 2014.

[35] M. W. J. I. J. o. E. Njagi and Research, "The Effects of Differentiated Instruction on Students Achievement in Mathematics by Gender in Secondary Schools in Meru County in Kenya," vol. 3, no. 3, pp. 377-386, 2015.

[36] M. O. Odumosu and P. A. J. I. J. o. D. M. Bankole, "A simplified Approach to students' Learning of Equivalent solutions to some Integral Calculus Problems," vol. 3, no. 1, pp. 2127, 2018.

[37] T. Palmer, M. J. P. S. I. P. F. o. t. R. F. t. D. o. M. o. S. i. E. C. Maag, and W. Instruction University of Wisconsin Oshkosh Oshkosh, "Differentiating instruction to challenge all students," vol. 54901, 2010.

[38] F. Precke and M. Brüll, "Grouping the gifted and talented: Are gifted girls most likely to suffer the consequences?," vol. 32, no. 1, pp. 54-85, 2008. https://doi.org/10.4219/jeg-2008822

[39] N. Raud and O. J. I. J. o. M. Orehhova, "Training teachers for multilingual primary schools in Europe: key components of teacher education curricula," pp. 1-13, 2020. https://doi.org/10.1080/14790718.2020.1718678

[40] S. M. Reis, D. B. McCoach, C. A. Little, L. M. Muller, and R. Kaniskan, "The effects of differentiated instruction and enrichment pedagogy on reading achievement in five elementary schools," vol. 48, no. 2, pp. 462-501, 2011. https://doi.org/10.3102/0002831210382891

[41] A. Rihab Salah Khairy, Haider TH. Salim ALRikabi2, "The Detection of Counterfeit Banknotes Using Ensemble Learning Techniques of AdaBoost and Voting," International Journal of Intelligent Engineering and Systems, vol. 14, no. 1, pp. 326-339, 2021. https://doi.org/10.22266/ijies2021.0228.31

[42] A. Roy, P. André, D. Arzoumanian, M.-A. Miville-Deschênes, V. Könyves, N. Schneider, S. Pezzuto, P. Palmeirim, J. Kirk, and Astrophysics, "How the power spectrum of dust continuum images may hide the presence of a characteristic filament width," vol. 626, p. A76, 2019. https://doi.org/10.1051/0004-6361/201832869

[43] A. M. Salama, Spatial design education: New directions for pedagogy in architecture and beyond. Routledge, 2016. 
[44] B. E. Scott, "The effectiveness of differentiated instruction in the elementary mathematics classroom," 2012.

[45] B. Sevinc, H. Ozmen, and N. Yigit, "Investigation of Primary Students' Motivation Levels towards Science Learning," vol. 22, no. 3, pp. 218-232, 2011.

[46] K. Siam and M. Al-Natour, "Teacher's Differentiated Instruction Practices and Implementation Challenges for Learning Disabilities in Jordan," vol. 9, no. 12, pp. 167-181, 2016. https://doi.org/10.5539/ies.v9n12p167

[47] P. M. Simpkins, M. A. Mastropieri, T. Scruggs, and S. Education, "Differentiated curriculum enhancements in inclusive fifth-grade science classes," vol. 30, no. 5, pp. 300-308, 2009. https://doi.org/10.1177/0741932508321011

[48] K. Singh, M. Granville, and S. J. T. j. o. e. r. Dika, "Mathematics and science achievement: Effects of motivation, interest, and academic engagement," vol. 95, no. 6, pp. 323-332, 2002. https://doi.org/10.1080/00220670209596607

[49] W. Smets and K. J. E. S. Struyven, "Realist review of literature on catering for different instructional needs with preteaching and extended instruction," vol. 8, no. 3, p. 113, 2018. https://doi.org/10.3390/educsci8030113

[50] R. Smit, W. J. T. Humpert, and T. Education, "Differentiated instruction in small schools," vol. 28, no. 8, pp. 1152-1162, 2012. https://doi.org/10.1016/j.tate.2012.07.003

[51] S. Stollman, "Differentiated instruction in practice: a teacher perspective," vol. 3, no. 20, p. 6, 2018.

[52] C. Tieso, "The effects of grouping practices and curricular adjustments on achievement," vol. 29, no. 1, pp. 60-89, 2005.

[53] C. Tomlinson, Differentiating instruction for advanced learners in the mixed-ability middle school classroom. ERIC Clearinghouse on Disabilities and Gifted Education Reston, VA, 1995.

[54] C. Tomlinson, The differentiated classroom: Responding to the needs of all learners. Ascd, 2014.

[55] C. Tomlinson and M. B. Imbeau, Leading and managing a differentiated classroom. ASCD, 2010.

[56] C. Tomlinson, "Sharing responsibility for differentiating instruction," vol. 26, no. 4, p. 188, 2004.

[57] C. Tomlinson, "Grading and differentiation: Paradox or good practice?," vol. 44, no. 3, pp. 262-269, 2005.

[58] A. UNESCO, "A guide for ensuring inclusion and equity in education," Geneva: UNESCO IBE. https://unesd oc. unesc o. org/ark:/48223/pf000 2482, vol. 2482, p. 54, 2017.

[59] S. Valiande and M. I. Koutselini, "Application and evaluation of differentiation instruction in mixed ability classrooms," in 4th Hellenic Observatory PhD Symposium, 2009, pp. 2526: Citeseer.

[60] W. Van Casteren, J. Bendig-Jacobs, F. Wartenbergh-Cras, M. van Essen, and B. Kurver, "Differentiëren en differentiatievaardigheden in het primair onderwijs," ed: Nijmegen: ResearchNed, 2017.

\section{Authors}

Dr. Najeh Rajeh Ibrahim Al Salhi is a Researcher of Educational Science, Education Department, College of Humanities and Sciences at Ajman University. Also, at Nonlinear Dynamics Research Center (NDRC), Ajman University, Ajman, UAE. He holds a Ph.D. degree in Curriculum and Methods of Science (Chemistry). Dr. Alsalhi 
Began His Career as A Public-School Science and Chemistry Teacher. He Also Served as Science \& chemistry Supervisor in The Ministry of Education, Jordan. He Also Served within the team's pivotal as an expert of science for authoring and computing Jordanian science curriculum Under the supervision of the Ministry of Education, Jordan Training Technology Group "Rubicon”. He is a Member of the Training beginner Teachers group in Jordan. He received his B.Sc. in Science "chemistry" from Al Yarmouk University in 1994 and his Master Degree in Education Science from The University of Juba, Sudan in 2001, and his Doctorate in Curriculum and Methods of Teaching Science "Chemistry" from the University of Omdurman - Sudan, 2013. Al Salhi Published Most of his Papers at Professional International Conferences and Scientific Journals.

Dr. Rasha M Abdelrahman is an assistant professor in Humanities and sciences college, Head of psychology department, Ajman University. She was graduated from Ain Shams University, Cairo, Egypt, with more than seventeen years' experience in teaching and research in the field of psychology, she is interested in research in many areas of psychology: cognitive psychology, Educational psychology, positive psychology and social psychology. She has a Coach for active parenting of teens certified by Active Parenting of teen's publishers, USA. With twenty years' experience in counseling, and more than twenty-three years' experience in training.

Dr. Atef Abdelkader, Assistant Prof. in physics, the Head of Math and Science department, Ajman University. I got my PhD In Physics, from The Queen's University (U.K.). My PhD project concerned the physics of $2 \mathrm{D}$ foam. This work was characterized by innovative experimental approaches and careful analysis. It set new standards in the field and settled two separate controversies in a rather final way. I also found novel and quite unexpected phenomena, which are still only partly understood. I have an interest in a number of areas like Optics-Lasers, Spectroscopy, and Optical System Technology - Any area where science is applied.

Dr. Sharif S. Ahmad Al-Yatim is An Educational Supervisor specializing in biology subjects in the Jordanian Ministries of Education. He holds a Ph.D. degree in Curriculum and Teaching specialized in Science Education, He was an Author of Electronic Science Curricula for all stages between 2004-2006, He participated in writing a book on curricula and their issues, and a teacher of curricular topics and issues within various educational programs for newest teachers. He Published several Educational Researches and participated in several educational Conference.

Dr. Mahmoud Abdel Lateef Habboush is a Supervisor, at Ministry of Education in Jordan. He holds a Ph.D. degree in Geology from University of Jordan in 2004. Dr. Habboush received his Master's Degree in Geology from University of Jordan, 1996, and Higher Diploma in Education from University of Jordan in 2001, and his B.Sc. in Geology from Yarmouk University in 1992. Dr. Habboush works in Rubicon Company as SME (Subject Matter Expert) - Electronic Education between 2004 and 2007 and in Obeican Company in Saudi Arabia as Science Editor and earth Science Curriculum Trainer between 2009-2017 and now he is a Co-author of Earth Sciences Books and Teachers' Guides for 10th and 11th grades in National Center for Curriculum Development-Jordan. 
Dr. Abdellateef Abdelhafez Al Qawasmi is Lead Teacher, at Ministry of Education UAE. He holds a Ph.D. degree in Curriculum and Methods of Science. Dr. Qawasmi began his career as a public-school physics teacher in Jordan. He received his B.Sc. in Science (majoring in Physics) from Yarmouk University in 1986, his Master's Degree in Education Science from Mu'tah University - Jordan, 1998, and his Doctorate Degree in Curriculum and Methods of Teaching Science from Amman Arab University for Graduate Studies - Jordan in 2010. Al Qawasmi is particularly interested in all eLearning-based aspects of education.

Article submitted 2021-02-24. Resubmitted 2021-03-23 Final acceptance 2021-03-26. Final version published as submitted by the authors. 